\title{
Understanding the Meaning of the Positive Bouguer Anomaly of Waza (Northernmost Cameroon, Central Africa)
}

\author{
Eyike Albert ${ }^{*}$, Basseka Charles Antoine ${ }^{2}$, Lordon Djieto Anatole Eugene ${ }^{3}$, \\ Nguimbous-Kouoh Jean Jacques ${ }^{4}$, Zanga-Amougou Alain ${ }^{1}$, Tabod Charles Tabod ${ }^{5}$
}

${ }^{1}$ Department of Physics, Faculty of Science, University of Douala, Douala, Cameroon

${ }^{2}$ Department of Earth Science, Faculty of Science, University of Douala, Douala, Cameroon

${ }^{3}$ Department of Geology, Faculty of Science, University of Buea, Buea, Cameroon

${ }^{4}$ Department of Gas and Petroleum Exploration, Institute of Mines and Petroleum Industries, University of Maroua, Maroua, Cameroon

${ }^{5}$ Department of Physics, Faculty of Science, University of Yaoundé 1, Yaoundé, Cameroon

Email: *aeyike@gmail.com

How to cite this paper: Albert, E., Antoine, B. C., Eugene, L. D. A., Jacques, N.-K. J., Alain, Z.-A., \& Tabod, T. C. (2019). Understanding the Meaning of the Positive Bouguer Anomaly of Waza (Northernmost Cameroon, Central Africa). Journal of Geoscience and Environment Protection, 7, 55-65.

https://doi.org/10.4236/gep.2019.76005

Received: April 25, 2019

Accepted: June 21, 2019

Published: June 24, 2019

Copyright $\odot 2019$ by author(s) and Scientific Research Publishing Inc. This work is licensed under the Creative Commons Attribution International License (CC BY 4.0).

http://creativecommons.org/licenses/by/4.0/

\begin{abstract}
Gravity and magnetic data were analyzed in conjunction with available geological data to determine the origin of observed positive gravity anomaly at Waza and its possible relationship to mafic intrusions. The data analysis includes the construction of a Bouguer gravity anomaly, isostatic residual gravity anomaly, total magnetic gradient and Euler solutions maps, and two and one-half dimensional gravity models. A positive gravity anomaly that occurs in Waza has amplitude of $35 \mathrm{mGal}$ and can be separated into two parts. The top of the disturbing body causing the anomaly cannot be deeper than 4 $\mathrm{km}$. We believe the anomaly is probably caused by a body of basaltic rocks lying at the upper surface of the Precambrian basement and originate from a self-propagating disturbance of magmatic loads on a pre-existing zone of lithospheric weakness. Melt migration might have been aided by tectonic and flexural stresses, such that the intrusion is limited in extent to the melting region of the plume and did not reach the surface. The model calculated to satisfy the observed anomaly consists of a $2.5 \mathrm{Km}$-thick slab underlain by a 10.5 $\mathrm{km}$ deep column. This model is interpreted to represent a sheet or saucer-like mafic intrusion that has a thick deep feeder. Detailed geophysical studies would be necessary to locate any possible economic occurrences.
\end{abstract}

\section{Keywords}

Northern Cameroon, Waza Bouguer High, Total Magnetic Gradient, Basaltic Intrusion 


\section{Introduction}

Geophysical data provide information about geological features which are hidden under the overburden and thus are not observable by conventional geological mapping. Considerable interest has focused on geophysical data bearing on subsurface structures of northern Cameroon and its surroundings. Many geophysical and geological investigations carried out in this area were aimed at modeling the geological formations and its associated basins. Generally, the negative anomalies are attributed to Cretaceous sediments with thicknesses (Eyike \& Ebbing, 2015; Eyike et al., 2010; Kamguia et al., 2005; Njandjock et al., 2006), while the positive residual Bouguer anomalies are due to the intrusions of igneous rocks or a shallow basement (Collignon, 1968; Ngounouno \& Deruelle, 1997). Detailed analyses and interpretation realized by combining existing $2 \mathrm{D}$ reflection seismic and Gravity/Magnetic data of the Logone Birni Basin (LBB) in the West and Central African Rift System (WCAS) have revealed the distribution of buried volcanic bodies as well as their relationships with the structural and tectonic evolution of this basin. The volcanic activity in the LBB is restricted to the Cretaceous period (Loule \& Pospisil, 2013; Mkoumbe et al., 2019). The volcanic bodies within the Lower Cretaceous are either lying directly on basement or are mainly interbedded with the contemporaneous sediments, whereas, the Upper Cretaceous bodies are morphologically expressed in the forms of dykes and sills (Loule \& Pospisil, 2013). Despite this intense scientific activity, the existence of a positive Bouguer anomaly seen on all Bouguer maps, and associated with the Wa$\mathrm{za}$ area has never been discussed. This Bouguer positive anomaly occupies an area of about $4000 \mathrm{~km}^{2}$ and shows the maximum amplitude signal in the area. In the North of Cameroon there are many small basins of Neocomian to early Aptian age (ca. 130 - $118 \mathrm{Ma}$ ) which are relatively thick and do not allow the geological surface expression of this positive anomaly. These small basins contain interstratified alkali basalt flows, associated with dolerite dykes and sills as well as post sedimentary intrusive igneous bodies which cut through the sedimendary sequence (Brunet et al., 1988; Loule et al., 1997). The timing of uplift of these intrusive bodies is in general poorly constrained and this remains an area for further research. The aim of this study is to determine the detailed depth information of anomalous sources of Waza and explain its positive gravity anomaly.

\section{Regional Geology}

The northernmost Cameroon which is the focus of this study area is blanketed by Quaternary sediments and belongs to the West and Central African Rift System (WCAS) (Figure 1). The genesis of the WCAS sedimentary basins is characterized by polyphase rifting separated by tectonic events that can be recognized as regional deformation (folding), hiatus of sedimentation and non-conformities in both seismic sections and outcrops.

These basins and particularly the LBB, are the product of a complex period of continental disruption, as Africa responded to plate tectonic fragmentation of 


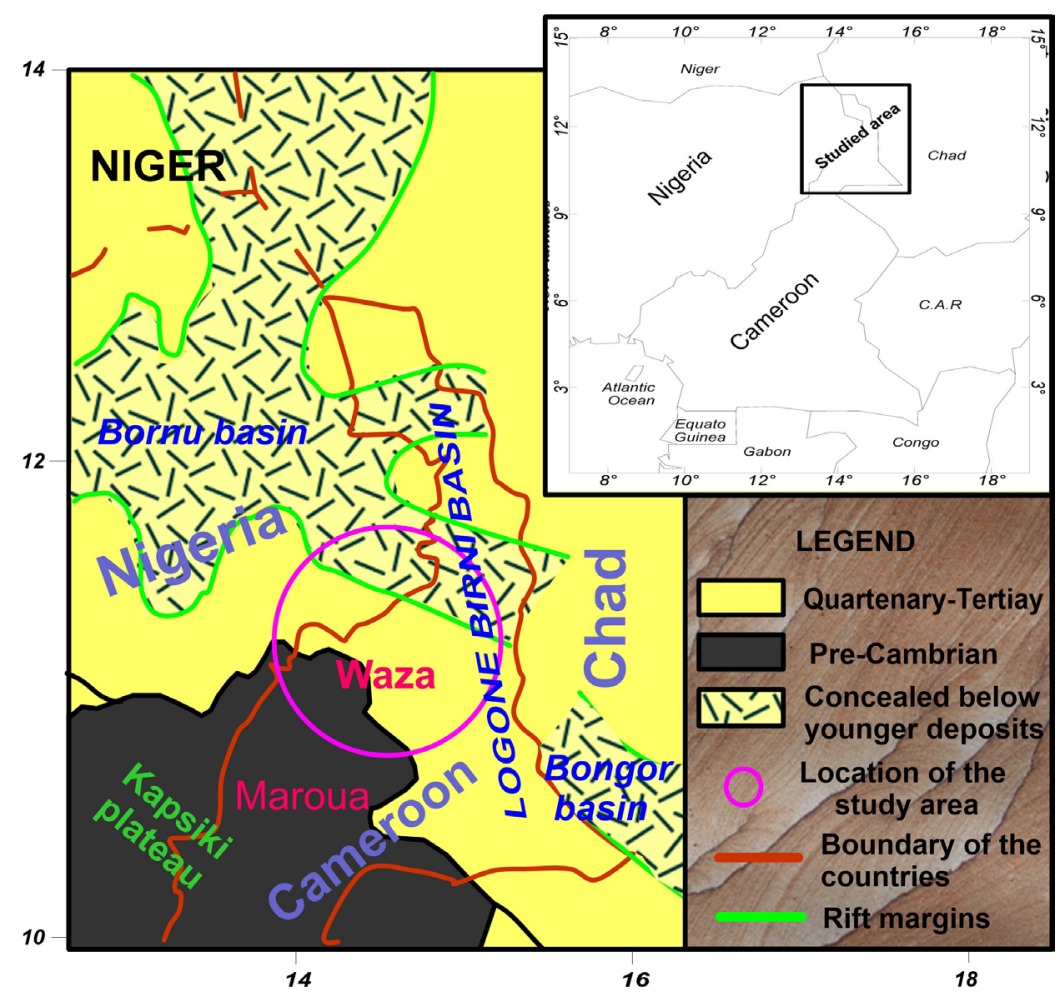

Figure 1. Simplified geological presenting geological features and major tectonic directions of Cameroon and approximate positions of some locations.

the Gondwana. From literature, three main mechanisms have been described to account for such continental disruption. These are: up-doming of the crust over a hot-spot, asthenospheric mantle rise to high levels beneath existing fractures, and convective processes in the underlying asthenosphere. Three main episodes of basin development have been documented after the Pan-African crustal consolidation (750 - $550 \mathrm{Ma}$ ) and the Paleozoic-Jurassic platform development (550 - $130 \mathrm{Ma})$. Rifting initiated during Neocomian to Aptian (130 Ma) resulted in the communication between the WCAS and the West African Salt Basins (WASB). The grabens formed were re-opened during Aptian-Albian in a regime of oblique extension (Avbovbo et al., 1986; Benkhelil, 1982; Genik, 1992). These rifting events were followed by thermal tectonic subsidence within the rifts (80 $75 \mathrm{Ma}$ ). The thermal subsidence was accompanied by a major marine transgression which reached northern Cameroon from the Tethys, to the North, through Mali and Algeria and from the South Atlantic, to the South, via the Benue Trough into western Chad and Niger. This transgression reached its maximum eastern extent in the westernmost end of the Doba basin at 85 - $80 \mathrm{Ma}$ (Genik, 1992). It was followed by a regression of the sea due to an epeirogenic uplift. By $75 \mathrm{Ma}$, the shallow seas had regressed leaving behind a regional unconformity which is documented in many basins in central and northeast Africa as well as in South Atlantic and in northeast Brazil. The last episode of development (30 Ma-Present), is a post rift stage during which most of the area was uplifted. This emergent stage was accompanied by some uplifting in the East of the Cameroon 
Volcanic Line in the Adamawa region (Fitton, 1980) giving way to the erosion of high lands, where up to $2500 \mathrm{~m}$ of sediments were eroded in the western parts of the Doba and Bongor basins and up to $500 \mathrm{~m}$ of continental sediments were deposited in the present location of Lake Chad (Genik, 1992; Mothersill, 1975). Volcanism is recorded in the WCAS from Early Cretaceous through Tertiary (Loule \& Pospisil, 2013).

\section{Data Processing and Analysis}

The measured gravity field (Figure 2(a)) in North Cameroon usually shows the combined effect of a local associated with the superficial rocks and a regional caused by deeper structures in the earth's crust (Eyike et al., 2010). Thus, to effectively use Bouguer gravity data to infer the properties of the anomaly of Waza the gravity anomalies that is due to this feature must be enhanced. To aid in this enhancement, we use the isostatic residual anomalies. Determining the isostatic residual gravity anomalies is a technique based on geologically estimated parameters (density of the topography, depth of compensation, and density between a crustal root and the surrounding material) and thus is more likely to produce gravity anomalies resulting from crustal sources (Simpson et al., 1986) than polynomial trend surface fitting or wavelength filtering. The one problem in North Cameroon is that there are no detailed studies of the thickness of the crust and the only regional studies do not provide the constraints necessary to determine the isostatic compensation parameters. However, from Eyike and Ebbing (2015);
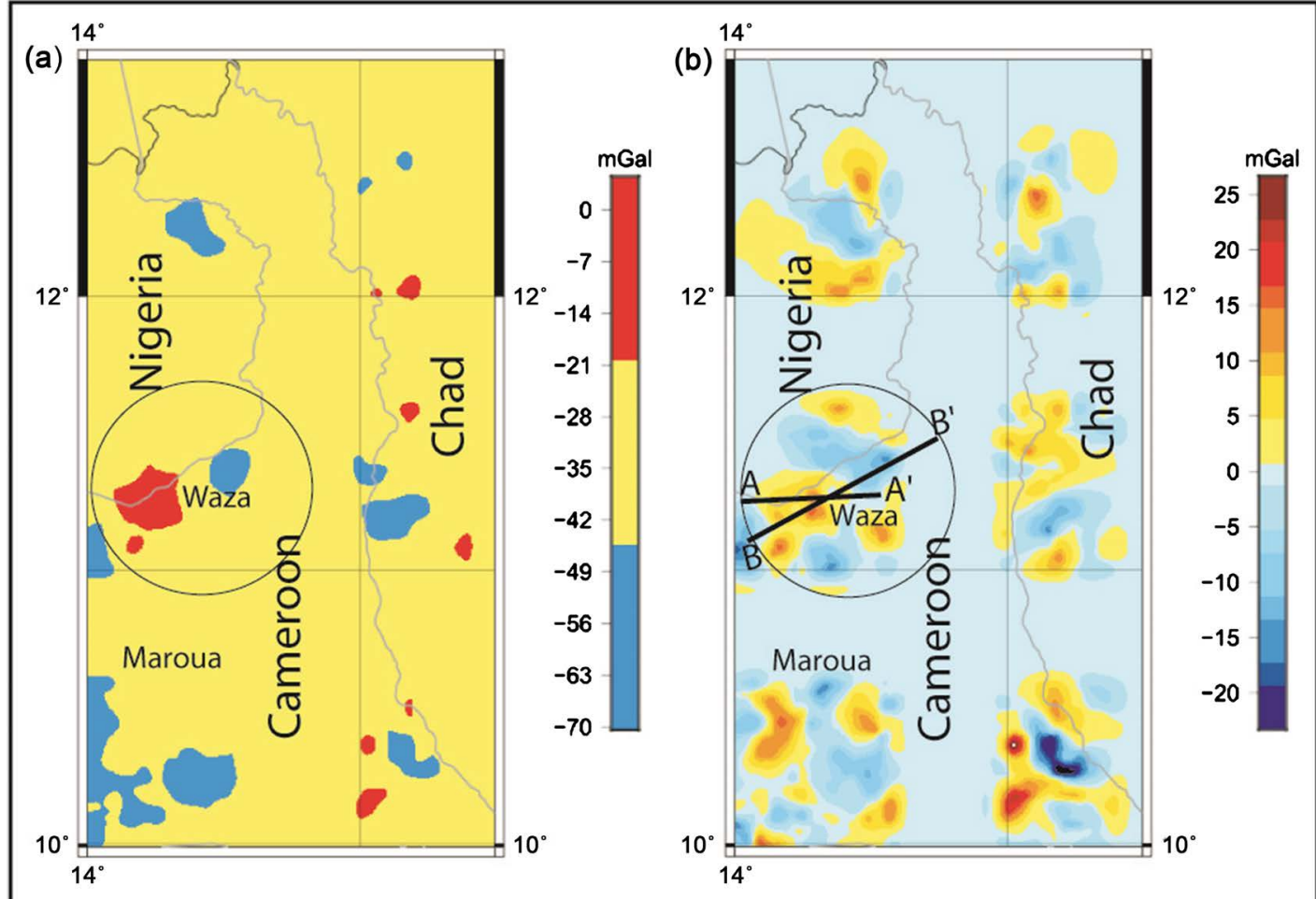

Figure 2. (a) Bouguer gravity anomaly map of North Cameroon; (b) This isostatic residual gravity anomaly map, superimposed on it are the selected profiles A-A' and B-B' used for the modeling. 
Tokam et al. (2010) and Poudjom Djomani et al. (1995), an average compensation depth of $33 \mathrm{~km}$, the topography density $(2.67 \mathrm{~g} / \mathrm{cc})$ and density contrasts across crustal root were estimated from the Christensen and Mooney (1995) $P$-wave velocity-density empirical relationship. Crust layer velocities used and estimated densities for the layers are provided in Table 1 . These values plus a topography grid (Amante \& Eakins, 2008) were combined to create an isostatic residual gravity anomaly map.

This isostatic residual gravity anomaly map (Figure 2(b)) has a similar appearance to the Bouguer gravity anomaly map but there are subtle differences. This is more evident in the south-east of the map where the difference between the minima is greater. Based on the given data, the isostatic residual gravity anomaly map probably shows the best representation of upper crustal gravitational sources. The isostatic residual gravity anomaly map has anomalies that range in value between -40 and $+35 \mathrm{mGal}$ with all of the anomalies having a relatively short wave length. The main negative anomalies are located in the Logone Birni basin (LBB) area and in the zones surrounding the Kapsiki Plateau. In the area of Yagoua, there is a large circular anomaly with a minimum of -20 $m$ Gal. This anomaly is limited on the East by smaller negative anomalies that form an arc. The Central part of the LBB is characterized by a minimum of -25 mGal trending mainly NW-SE and extending from Cameroon up to the Republic of Chad. The most striking positive anomaly is located in the west area of Hinale is characterized by a high at Waza with a value of $35 \mathrm{mGal}$, suggesting high density material in the subsurface. Moreover, this high gravity seems to be composed of two components. The one is the broad circular trending feature whose upper value is about $35 \mathrm{mGal}$. The other component of the gravity high is the almost N-S trending closure characterized by high gradient with the maximum anomaly of about $20 \mathrm{mGal}$. High gradient in the gravity field suggests that the cause of this anomaly lies at relatively shallow depth. The cause of this anomaly must be a geologic feature with a positive density contrast and a large mass excess relative to the surrounding crustal rocks. For the deeper analysis of the gravity anomalies, two profiles A-A' and B-B' are drawn across the High.

\section{Results and Discussion}

The interpretation was performed as model computations for two profiles across the high by creating a two and one half dimensional gravity model along the traverses A-A' and B-B' (Figure 2(b)). In two and one half dimensional modeling,

Table 1. Density values used for the gravity modeling. Densities of crustal units are obtained by using the relationship between $P$-wave velocity and density (Christensen \& Mooney, 1995).

\begin{tabular}{ccc}
\hline$P$-wave velocity $(\mathrm{m} / \mathrm{s})$ & Density $\left(\mathrm{kg} / \mathrm{m}^{3}\right)$ & \\
\hline $2000-4500$ & $2000-2490$ & Sediment cover \\
$5500-6000$ & $2650-2710$ & Basement \\
\hline
\end{tabular}


the model is taken as having a finite length perpendicular to the profile rather than infinite length in this dimension as assumed in two dimensional modeling. The computations were performed by GMSYS modeling program. It is evident that an interpretational problem of this type cannot be uniquely solved by one set of computed models with a satisfactory fit. However, the geological and petrophysical data established for the area (Eyike \& Ebbing, 2015; Loule \& Pospisil, 2013), and the calculated Euler depths (Figure 3) considerably limit the number of possible models. The key elements of these models are the requirements for a high density contrast $\left(500 \mathrm{~kg} / \mathrm{m}^{3}\right)$ and a deep narrow block on profile A-A'. Since the addition of more material at the base of this block has only a small effect, the actual figure for the depth of the base cannot be taken laterally. The SW and the NE ends contacts of the upper slab probably dip steeper because of the high gradient here.

The shape of the model that satisfies the observed gravity anomalies is an elongated Nord-South slab underlain by a deep vertical stem whose oval cross section has an East-West trending longer axis (Figure 4). Because their exact position is unknown, the attitudes of contacts for the slab cannot be determined with certainty; however, the calculated model probably represents the gross overall shape of the geologic body.

Both scattered geologic observations and gravity anomalies indicate that much of the North Cameroon is underlain by sparse igneous intrusions which lie at the surface of the Precambrian (Eyike \& Ebbing, 2015; Loule \& Pospisil, 2013;

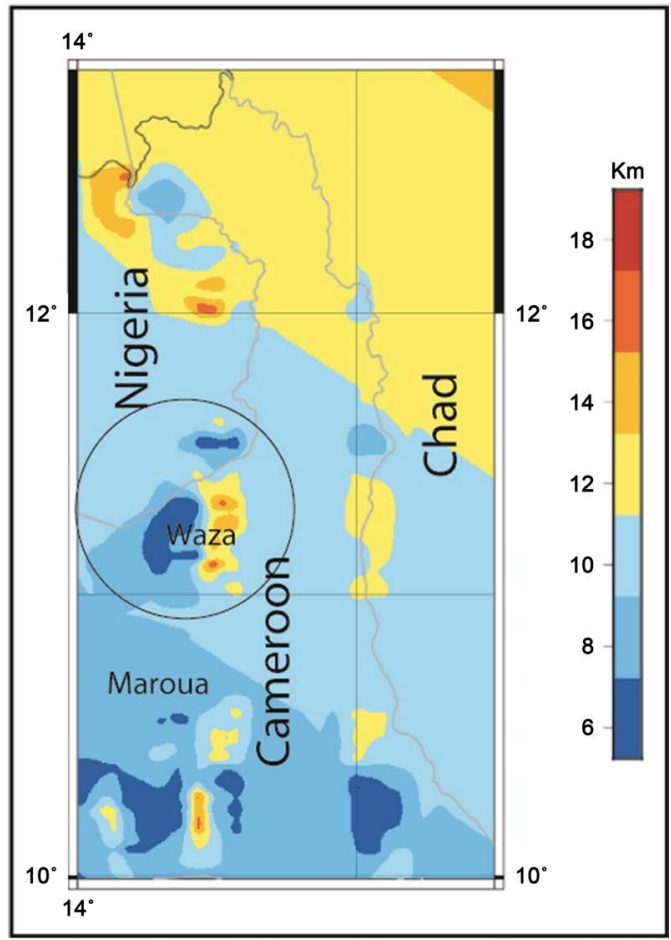

Figure 3. Euler solutions calculated from the residual gravity for the structural indices $(S I)=3$, with depth uncertainty set at maximum of $5 \%$. The Euler solutions were then gridded to obtain the Euler solutions map representing the variation of source and depth positions. 


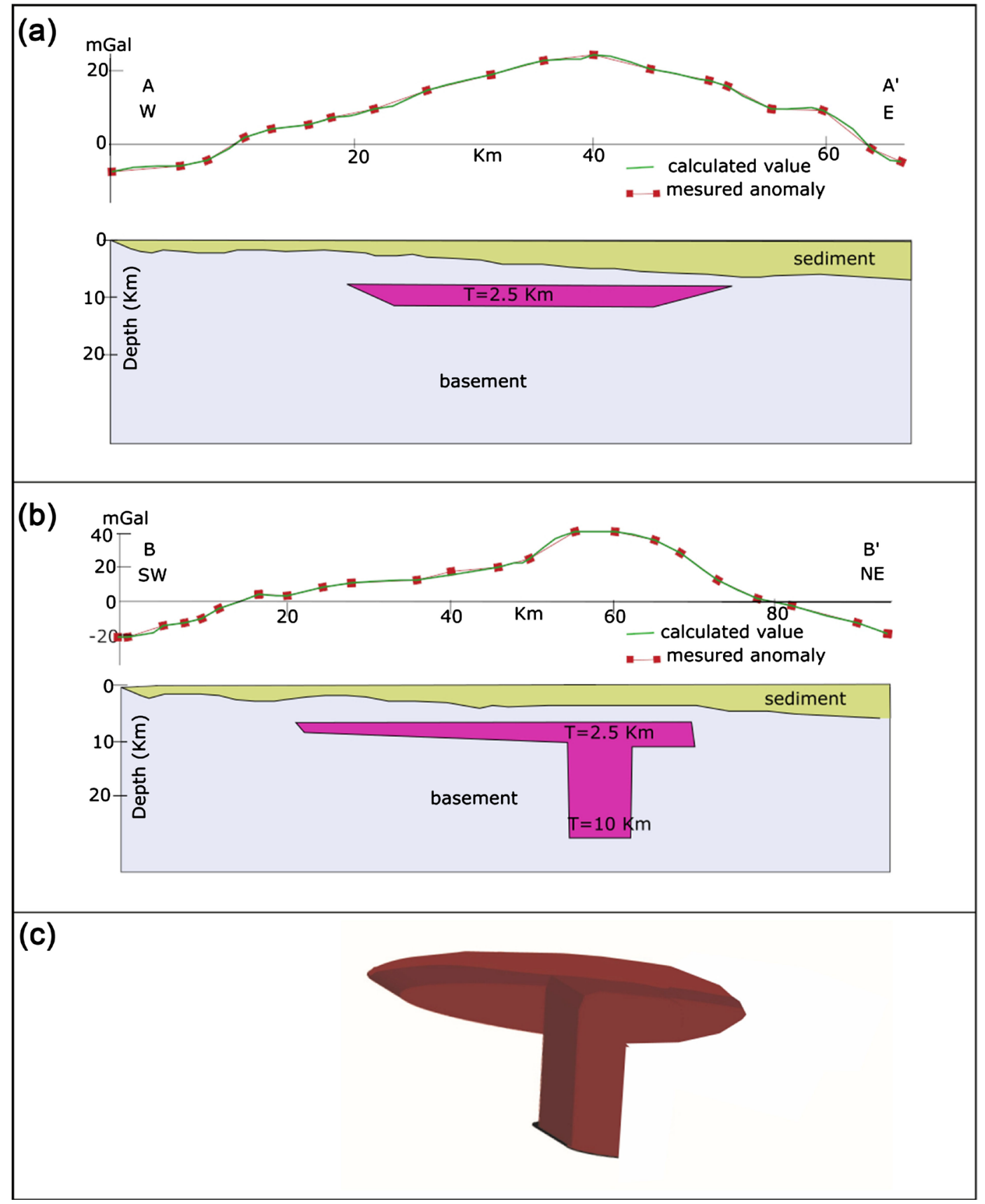

Figure 4. Profiles through the gravity anomaly and models calculated to approximate the anomaly. (a) Profile A-A'; (b) Profile B-B'; (c) Three-dimensional representation of the body calculated to simulate the gravity anomaly-viewed from the side and below.

Eyike et al., 2010; Ngounouno et al., 2000). From the geometry of the causative body and the high total magnetic gradient (Figure 5(b)), we believe that this anomaly is likely to be a lopolith intrusion of igneous origin, or a series of lavas which have accumulated to substantial thickness over a limited area. A density contrast of 300 to $500 \mathrm{~kg} / \mathrm{m}^{3}$ argues in favor of igneous mafic intrusions because intrusive igneous rocks have considerably higher densities than the lavas, and there is no molten or partially molten rocks detected in this area. 


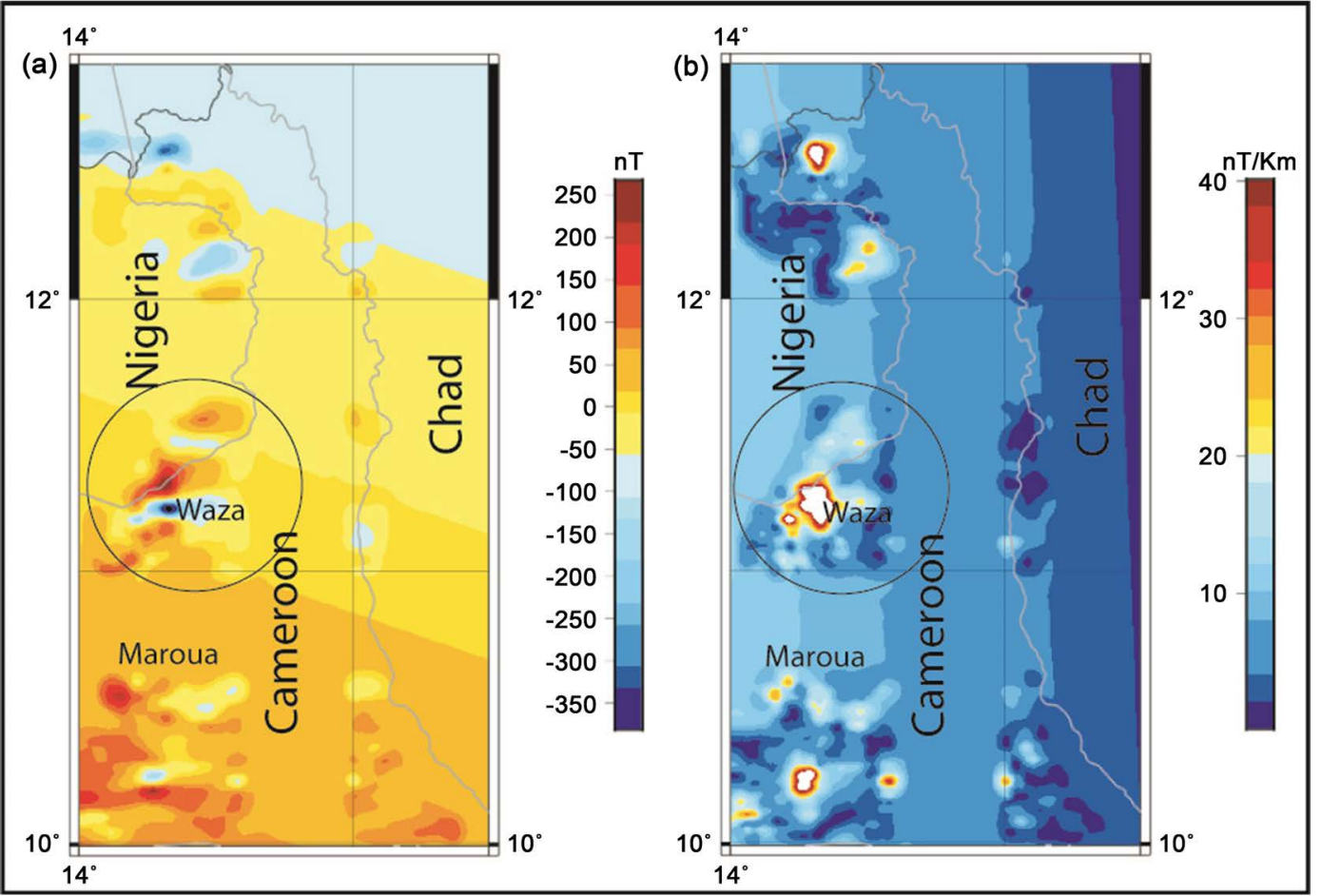

Figure 5. (a) Aeromagnetic anomaly map of North Cameroon; (b) Analytic Signal of the magnetic field of the North Cameroon area. The aeromagnetic data in the area of study were provided by GETECH. They are part of African Magnetic Mapping Project AMMP dataset compiled in 1989 on the basis of an accumulated knowledge of the considerable extent of magnetic coverage that existed in the continent of Africa.

Loule and Pospisil (2013) have described the magmatic activity in the area of study has been related to the evolution of the Logone Birni Basin that occurred in the Cretaceous time. Ngounouno et al. (2000) testified that most of the resulted igneous rocks were small in size. If the causative body is an igneous intrusive, similar to those inferred from the tectonic history of the Logone Birni Basin (Avbovbo et al., 1986; Benkhelil, 1982; Genik, 1992), then the lateral extension of the causative body could be smaller than that observed in our model, even though igneous intrusions may be highly variable in shape and composition. It is unlikely, however, even if the anomaly is caused by an intrusion, that it is related to the evolution of the Logone Birni Basin. In the case of the Waza anomaly, we suggest a confine intrusive zone of intraplate magmatism. There is no actual tectonic or geological knowledge susceptible to explain the nature and the origin and the geometry structure of the Waza anomaly. However, regarding the nature, the sampling map produced by Ngounouno et al. (2000) in the Kapsiki Plateau, southwest of Waza, argue in favor basaltic rocks resulting from the fractional crystallization of basaltic magma. Further, this area belongs to the large scale Niger-Nigeria and Cameroon magmatic provinces across the African plate. We may therefore speculate that the Waza high may have followed the similar tectonic history of this province proposed by Ngako et al. 2006. The model of Ngako et al., 2006 is based the Hieronymus and Bercovici (2000) theory which explains the distribution of non-hotspot island and seamount chains in terms of 
the vulnerability of the lithosphere to magma penetration due to lithospheric stresses and the effects of melting of the conduit walls. Their theory is based on the assumption that 1) transport of magma through the brittle part of the lithosphere occurs via fractures and 2) melt is uniformly distributed at the base of the lithosphere. It turns out that an initial perturbation is required in all cases to localize the volcanic activity. This initial perturbation may be provided by a change in the tectonic stress field due to a plate motion re-organization (which is amplified locally by an inhomogeneity in the lithosphere), the formation of a small sub lithospheric melting anomaly or a change in convection. Following the above hypothesis and due to some local perturbations in the area already mentioned in Ngako et al. (2006), we suggest for the Waza anomaly, a self-propagating disturbance of magmatic loads on a pre-existing zone of lithospheric weakness. Binks and Fairhead (1992) and Guiraud et al. (1992) showed that the development of the Early Cretaceous to Palaeogene West and Central African rift system, caused reactivation of pre-existing zones of lithospheric weakness and hence, providing conduits for magma migration. Compared to East Africa, the intrusion of Waza seems limited in extent. Melt migration might have been probably aided by tectonic and flexural stresses, such that the intrusion is limited in extent to the melting region of the plume and did not reach the surface. Another possibility is however that magma accumulation processes have not persisted over long time and consequently causing the limited extent of the intrusion.

\section{Conclusion}

The Waza positive anomaly corresponds in position with mafic rocks occurring in Precambrian window. Calculations show that the source of this anomaly must lie at relatively shallow depth. In this area, Precambrian rocks are covered by Cretaceous to Recent sediments. The source of the anomaly must most be in the Precambrian basement and is most likely at the surface of the Precambrian. The positive anomaly of Waza is approximated by a model composed of a thin horizontal plate with a large feeder in the middle. Since sufficient geologic control is not available, the proposed model can hardly be regarded as unique; however, it is probably plausible in its gross features. The shape of the model is consistent with a flat or saucer-shape intrusion underlined by a thick deep feeder. The Waza anomaly is in any case, probably caused by basaltic intrusion which could contain mineral deposit. Detailed geophysical studies would be necessary to locate any possible economic occurrences.

\section{Acknowledgements}

We are very grateful to Alain Pierre Tokam for making available the density constrains.

\section{Conflicts of Interest}

The authors declare no conflicts of interest regarding the publication of this paper. 


\section{References}

Amante, C., \& Eakins, B. W. (2008). ETOPO1, 1 Arc-Minute Global Relief Model: Procedures, Data Sources and Analysis. Boulder, CO: National Geophysical Data Center, NESDIS, NOAA, U.S. Department of Commerce.

Avbovbo, A. A., Ayoola, E. O., \& Osahon, G. A. (1986). Depositional and Structural Styles in Chad Basin of Northeastern Nigeria. AAPG Bulletin, 70, 1787-1798. https://doi.org/10.1306/94886D21-1704-11D7-8645000102C1865D

Benkhelil, J. (1982). Benue Trough and Benue Chain. Geology Magazine, 119, 158-168. https://doi.org/10.1017/S001675680002584X

Binks, R. M., \& Fairhead, J. D. (1992). A Plate Tectonic Setting for the Mesozoic Rifts of Western and Central Africa. Tectonophysics, 213, 141-151. https://doi.org/10.1016/B978-0-444-89912-5.50034-X

Brunet, M., Dejax, J., Brillanceau, A., Congleton, J., Downs, W., Duperon-Laudoueneix, M., Eisenmann, V., Flanagan, K., Flynn, L., Heintz, E., Hell, J., Jacobs, L., Jehenne, Y., Ndjeng, E., Mouchelin, G., \& Pilbeam, D. (1988). Mise en évidence d'une sedimentation précoce d'âge Barrémien dans le fossé de la Bénoué en Afrique occidentale (Bassin du Mayo Oulu Léré, Cameroun), en relation avec l'ouverture de l'Atlantique sud. Comptes Rendus de l'Académie des Sciences Paris, 306, 1125-1130.

Christensen, N. I., \& Mooney, W. D. (1995). Seismic Velocity Structure and Composition of the Continental Crust: A Global View. Journal of Geophysical Research: Solid Earth, 100, 9761-9788. https://doi.org/10.1029/95JB00259

Collignon, F. (1968). Gravimetrie de Reconnaissance (35 p.). Cameroun: Rapport ORSTOM.

Eyike, A., \& Ebbing, J. (2015). Lithospheric Structure of the West and Central African Rift System from Regional Three-Dimensional Gravity Modelling. South African Journal of Geology, 118, 285-298. https://doi.org/10.2113/gssajg.118.3.285

Eyike, A., Werner, S. C., Ebbing, J., \& Dicoum, E. M. (2010). On the Use of Global Potential Field Models for Regional Interpretation of the West and Central African Rift System. Tectonophysics, 492, 25-39. https://doi.org/10.1016/j.tecto.2010.04.026

Fitton, J. G. (1980). The Benue Trough and Cameroon Line-A Migrating Rift System in West Africa. Earth and Planetary Science Letters, 51, 132-138. https://doi.org/10.1016/0012-821X(80)90261-7

Genik, G. J. (1992). Regional Framework, Structural and Petroleum Aspects of Rift Basins in Niger, Chad and Central African Republic (C.A.R.). Tectonophysics, 213, 169-185. https://doi.org/10.1016/0040-1951(92)90257-7

Guiraud, R., Binks, R. M., Fairhead, J. D., \& Wilson, M. (1992). Chronology and Geodynamic Setting of Cretaceous-Cenozoic Rifting in West and Central Africa. Tectonophysics, 213, 227-234. https://doi.org/10.1016/0040-1951(92)90260-D

Hieronymus, C. F., \& Bercovici, D. (2000). Non-Hotspot Formation of Volcanic Chains: Control of Tectonic and Flexural Stresses on Magma Transport. Earth and Planetary Science Letters, 181, 539-554. https://doi.org/10.1016/S0012-821X(00)00227-2

Kamguia, J., Manguelle-Dicoum, E., Tabod, C. T., \& Tadjou, J. M. (2005). Geological Models Deduced from Gravity Data in the Garoua Basin, Cameroon. Journal of Geophysics and Engineering, 2, 147-152. https://doi.org/10.1088/1742-2132/2/2/009

Loule, J. P., \& Pospisil, L. (2013). Geophysical Evidence of Cretaceous Volcanics in Logone Birni Basin (Northern Cameroon), Central Africa, and Consequences for the West and Central African Rift System. Tectonophysics, 583, 88-100. https://doi.org/10.1016/j.tecto.2012.10.021

Loule, J. P., Angoua Biouele, S. E., Seme Abomo, R., \& Tamfu, S. (1997). Timing of the 
Communication between the South and Central Atlantic Using Palynological Data from Eight Wells in the Douala/Kribi-Campo Basin, Cameroon. In Second Annual Conference IGCP Project (Vol. 381, pp. 8-13).

Mkoumbe, E., Fosso Téguia M. E. E., Eyike Yomba, A., Njandjock Nouck, P., \& Tabod, T. C. (2019). Depositional and Structural Styles in the Logone Birni Basin (LBB), Northern Cameroon, from 3D Potential Field Modeling: Preliminary Results. Open Journal of Geology, 9, 226-244. https://doi.org/10.4236/ojg.2019.94016

Mothersill, J. S. (1975). Lake Chad: Geochemistry and Sedimentary Aspects of a Shallow Polymictic Lake. Journal of Sedimentary Research, 45, 295-309. https://doi.org/10.1306/212F6D48-2B24-11D7-8648000102C1865D

Ngako, V., Njonfang, E., Tongwa, A. F., Afaton, P., \& Nnange, M. J. (2006). The North-South Paleozoic to Quaternary Trend of Alkaline Magmatism from Niger-Nigeria to Cameroon: Complex Interaction between Hotspots and Precambrian Faults. Journal of African Earth Sciences, 45, 241-256.

https://doi.org/10.1016/j.jafrearsci.2006.03.003

Ngounouno, I., \& Deruelle, B. (1997). Données nouvelles sur le volcanisme cénozoïque du plateau Kapsiki (Nord du Cameroun). Comptes rendus de l'Académie des sciences. Série 2. Sciences de la terre et des planètes, 324, 285-292. https://doi.org/10.1016/S1251-8050(97)83968-7

Ngounouno, I., Deruelle, B., \& Demaiffe, D. (2000). Petrology of the Bimodal Cainozoic Volcanism of the Kapsiki Plateau (Northernmost Cameroon, Central Africa). Journal of Volcanology and Geothermal Research, 102, 21-44. https://doi.org/10.1016/S0377-0273(00)00180-3

Njandjock, N. P., Manguelle-Dicoum, E., Ndougsa-Mbarga, T., \& Tabod, C. (2006). Spectral Analysis and Gravity Modeling in the Yagoua, Cameroon Sedimentary Basin. Geofisica International, 45, 209-215.

Poudjom Djomani, Y. H., Nnange, J. M., Diament, M., Ebinger, C. J., \& Fairhead, J. D. (1995). Effective Elastic Thickness and Crustal Thickness Variations in West-Central Africa Inferred from Gravity Data. Journal of Geophysical Research, 100, 22047-22070. https://doi.org/10.1029/95JB01149

Simpson, R. W., Jachens, R. C., Blakely, R. J., \& Saltus, R. W. (1986). A New Isostatic Residual Gravity Map of the Conterminous United States with a Discussion on the Significance of Isostatic Residual Anomalies. Journal of Geophysical Research: Solid Earth, 91, 8348-8372. https://doi.org/10.1029/JB091iB08p08348

Tokam, A. P., Tabod, C. T., Nyblade, A., Julia, J., Wiens, D. A., \& Pasyanos, M. E. (2010). Structure of the Crust beneath Cameroon, West Africa, from the Joint Inversion of Rayleigh Wave Group Velocities and Receiver Functions. Geophysical Journal International, 183, 1061-1076. https://doi.org/10.1111/j.1365-246X.2010.04776.x 